\title{
ANALYSIS OF WORTH ASSESSMENT OF INFORMATION SOURCES OF ARTISANAL FISH FARMERS IN SELECTED COASTAL AREAS OF NIGERIA
}

\author{
Gbarabe Roland $^{1 *}$, Simon Letsoalo ${ }^{2}$ \\ ${ }^{1 * 2}$ North-West University, Department of Agricultural Economics and Extension, \\ Faculty of Natural and Agricultural Sciences, South Africa; \\ *Corresponding Author Gbarabe Roland email: womotimi@yahoo.com;
}

Received June 2019; Accepted July 2019; Published August 2019;

DOI: https://doi.org/10.31407/ijees9319

\begin{abstract}
Information sources play a vital role in improvement of artisanal fish farming, however, the different sources of information do not receive equal attention by artisanal fishers, and as a result the worth assessment of information sources used by artisanal fish farmers in selected coastal states of Nigeria was conducted. The study was carried out in the coastal States of Bayelsa, Rivers and Akwa Ibom in Nigeria. The data for this study was obtained from primary sources using questionnaire. Descriptive and inferential statistical analysis was employed. The result from the findings indicates that the majority of artisanal fish farmers were male (79.90\%). Artisanal fish farmers are predominantly adults as the result shows that most $(43 \%)$ fall within the age bracket of $41-50$ years. Few of the respondents $(23=5.2 \%)$ have been engaged in fish farming for the past 15 years and above. Majority $(88 \%)$ of the artisanal fish farmers had one form of education or the other. Majority of artisanal fish farmers 243 (55\%) earn monthly income between $\$ 11,000$ - $\$ 50,000$. Coastal artisanal fishers' information is highly motivated by farmers groups, Posters, Neighbour farmers, Co-operatives, Community leaders, Cell phones, Extension agents, Church meetings, input dealers, Output buyers and Credit agencies. The regression analysis revealed that there is significant relationship between the socio-economic characteristics of artisanal fish farmers and their information worth assessment. The researcher recommends that government and non-governmental agencies should provide literacy programmes to improve the education background of artisans and also provide comprehensible sources of information to enable artisans understand and increase output.
\end{abstract}

Key words: worthiness of information, information sources, artisanal fish farmers, coastal areas 